

\section{Sweden and ecological governance}

\footnotetext{
Published in our centenary year

$\approx 2004 \Longleftarrow$

MANCHESTER

UNIVERSITY

PRESS
} 


\section{Issues in Environmental Politics}

series editors Mikael Skou Andersen and Duncan Liefferink

At the start of the twenty-first century, the environment has come to stay as a central concern of global politics. This series takes key problems for environmental policy and examines the politics behind their cause and possible resolution. Accessible and eloquent, the books make available for a non-specialist readership some of the best research and most provocative thinking on humanity's relationship with the planet.

already published in the series

Science and politics in international environmental regimes Steinar Andresen, Tora Skodvin, Arild Underdal and Jørgen Wettestad

Congress and air pollution: environmental politics in the US Christopher J. Bailey

Implementing international environmental agreements in Russia Geir Hønneland and Anne-Kristin Jørgensen

The protest business? Mobilizing campaign groups Grant Jordan and William Maloney

Implementing EU environmental policy Christoph Knill and Andrea Lenschow (eds)

Environmental pressure groups Peter Rawcliffe

North Sea cooperation: linking international and domestic pollution control Jon Birger Skjoerseth

Climate change and the oil industry: common problem, varying strategies Jon Birger Skjoerseth and Tora Skodvin

European environmental policy: the pioneers Mikael Skou Andersen and Duncan Liefferink (eds)

Environmental policy-making in Britain, Germany and the European Union Rüdiger K. W. Wurzel 


\title{
Sweden and ecological governance
}

Straddling the fence

\author{
Lennart J. Lundqvist
}

Manchester University Press

Manchester and New York

distributed exclusively in the USA by Palgrave 
Copyright @ C Lennart J. Lundqvist 2004

The right of Lennart J. Lundqvist to be identified as the author of this work has been asserted by him in accordance with the Copyright, Designs and Patents Act 1988.

Published by Manchester University Press Oxford Road, Manchester M13 9NR, UK

and Room 400, 175 Fifth Avenue, New York, NY 10010, USA

www.manchesteruniversitypress.co.uk

Distributed exclusively in the USA by

Palgrave, 175 Fifth Avenue, New York,

NY 10010, USA

Distributed exclusively in Canada by

UBC Press, University of British Columbia, 2029 West Mall,

Vancouver, BC, Canada V6T 1 Z2

British Library Cataloguing-in-Publication Data

A catalogue record for this book is available from the British Library

Library of Congress Cataloging-in-Publication Data applied for

ISBN 0719069025 hardback

First published 2004

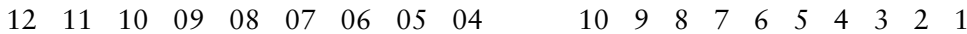

Typeset in Sabon

by Action Publishing Technology Ltd, Gloucester

Printed in Great Britain

by CPI, Bath 